\title{
Pembelajaran Kooperatif Tipe Team Game Tournament Pada Materi Ikatan Kimia Di Kelas X IPA SMA Negeri 1 Kotamobagu
}

\author{
Eka P. U. Mamangkai ${ }^{* a}$,Meytij J. Rampea, Jenny Kumajas ${ }^{a}$ \\ a Kimia, FMIPA, Universitas Negeri Manado, Minahasa, 95618, Indonesia
}

\begin{tabular}{l} 
I N F O A R T I K E L \\
\hline Diterima 03 September 2019 \\
Disetujui 27 Desember 2019 \\
\\
\hline Key word: \\
Learning outcomes, \\
cooperative chemistry, \\
learning bond \\
Type Team Games Tournament \\
\\
\hline Kata kunci: \\
Hasil belajar, \\
Ikatan kimia, \\
Pembelajaran kooperatif, \\
Tipe Team Games Tournament
\end{tabular}

${ }^{*}$ e-mail:

ekaputramamangkai@gmail.com ${ }^{*}$ Telp: 0895360584465

\begin{abstract}
A B S T R A C T
The purpose of this study was to determine the effect of guided inquiry-based Group The purpose of this study was to determine the effect of Team Games Tournament Cooperative learning on class X chemical bonding material at Kotamobagu 1 Public High School. This study used the experimental method and obtained samples, namely class X IPA A as the experimental class and class XIPA B as the control class. The process of collecting data by giving a test to students at the end of learning. The results showed that the average experimental class learning outcomes were higher than the control class. Based on the data analyzed using the t-test to test the research hypothesis and obtained tcount 8.95> t table 2,059, so that it can be concluded that there is a significant influence on the use of Team Games Tournament Type cooperative learning methods on learning outcomes in chemical bonding material.
\end{abstract}

\section{Pendahuluan}

Pengajaran kimia di lembaga-lembaga pendidikan merupakan salah satu aspek untuk menentukan keberhasilan dalam mencapai tujuan pendidikan nasional. Sebagai salah satu alat untuk mencapai pendidikan nasional maka tidak dipungkir lagi bahwa pengajaran kimia itu harus diajarkan dan harus dikembangkan. Dengan adanya pengajaran kimia di sekolah, maka peserta didik dapat mengetahui, memahami, menguasai, dan selanjutnya peserta didik dapat mengembangkan dan menggunakan kimia dalam kehidupan seharihari.

Banyak masalah yang didapat dalam pembelajaran kimia. Salah satunya adalah masih rendahnya daya serap siswa. Hal ini nampak dalam rerata hasil belajar siswa yang tidak memenuhi Kriteria Ketuntasan Minimal. Hasil belajar ini tentunya merupakan hasil kondisi pembelajaran yang masih bersifat langsung dan tidak menentu ranah dimensi siswa itu sendiri, proses pembelajaran yang masih berorientasu pada guru atau cenderung 
teacher-centered sehingga siswa tidak diberikan akses untuk berkembang secara mandiri dan siswa bersifat pasif.

Berdasarkan observasi yang dilakukan di sekolah SMA N 1 Kotamobagu, peneliti menemukan hasil belajar kimia siswa yang masih rendah. Hal ini nampak pada jumlah siswa yang mencapai Kriteria Ketuntasan Minimal yang ditetapkan oleh skolah yaitu 71 hanya 17 orang siswa dari 34 siswa atau sekitar $50 \%$ yang mencapai nilai Kriteria Ketuntasan Minimal. Hasil belajar siswa yang rendah ini disebabkan oleh guru jarang menggunakan metode pembelajaran bervariasi atau dengan kata lain guru hanya menggunakan metode ceramah dan resitasik(mengecek pemahaman dengan tanya jawab) atau pembelajaran langsung [1].

Team Games Tournament telah digunakan dalam berbagai macam pembelajaran, dan paling cocok untuk mengajar tujuan pembelajaran yang dirumuskan dengan tajam dengan satu jawaban benar, seperti perhitungan dan penerapan ciri kimia, dan fakta-fakta serta konsep IPA. Materi ikatan kimia adalah sebuah proses fisika yang bertanggung jawab dalam interaksi gaya tarik menarik antara dua atom atau molekul yang menyebabkan suatu senyawa diatomik atau poliatomik menjadi stabil, dan materi ini merupakan salah satu dari materi yang dapat diterapkan dengan menggunakan model pembelajaran kooperatif tipe Teams Games Tournament (TGT).

Dibandingkan dengan model pembelajaran kooperatif lainnya model pe,belajaran kooperatif tipe TGT dapat membuat siswa merasa senang karena ada unsur permainan. Dalam pembelajaran ikatan kimia siswa dapat belajar rileks dengan rasa bertanggung jawab, gotong royong, bersaing sehat, disamping itu juga ada unsur permainan dalam pembelajaran. Dengan cara seperti ini, proses pembelajaran diharapkan akan berlansung dengan menyenangankan dan para siswa dapat memahami materi ikatan kimia yang diperoleh dari proses belajar mengajar yang menggunakan Team Games Tournament [2].

\section{Metode}

Penelitian iyang digunakan adalah Eksperimen semu, dengan Postest Control Group Design. Dalam peneitian ini terdapat dua kelompok(kelas objek) yang ditetapkan secara random(acak). Rancangan postest control group deesign.

Tabel 1. Posttest Control Group Design

\begin{tabular}{lcc}
\hline \multicolumn{1}{c}{ Kelompok } & Perlakuan & Tes Akhir \\
\hline Eksperimen & $\mathrm{X}$ & $\mathrm{O}_{2}$ \\
\hline Kontrol & & $\mathrm{O}_{3}$ \\
\hline
\end{tabular}

Keterangan :

$\mathrm{O}_{1}$ : Skor tes akhir untuk kelas

eksperiment

$\mathrm{O}_{3}$ : Skor tes akhir untuk kelas kontrol

$X$ : Pengguna model kooperatif tipe TGT pada materi ikatan kimia.

Tehnik analisis data yang digunakan dalam penelitian ini adalah menganalisis data perbedaan hasil belajar siswa. Data hasil belajar tersebut dianalisis dengan menggunakan statistic uji t (uji perbedaan dua rata-rata)

\section{Hasil dan Pembahasan}

Sebelum instrumen penelitian diberikan kepada kelas yang menjadi sampel maka diuji validitas terlebih dahulu. Instrumen berupa soal objektif yang berjumlah 20 soal, diberikan kepada kelas yang telah mendapatkan materi elektrokimia. Instrumen dinyatakan valid apabila rhitung $>$ rtabel. Instrumen dapat dipercayai agar bisa digunakan sebagai alat pengukur data pada penelitian maka dilakukan uji reliabilitas. Data yang diperoleh dalam penelitian ini yaitu $\mathrm{r}_{11}=0,918$ dengan derajat reliabilitas tes yang di dapat yaitu tinggi, berarti instrumen reliabel.

\section{Deskripsi Data}

Penelitian ini dilaksanakan di SMA Negeri 1 yaitu IPA A sebagai kelas eksperimen sebanyak 25 siswa dan kelas IPA B sebagai kelas kontrol sebanyak 25 siswa. Penelitian ini data yang diambil adalah hasil belajar siswa yang diajarkan menggunakan model pembelajaran kooperatif tipe TGT dan hasil belajar siswa menggunakan model pembelajaran langsung pada materi ikatan kimia. Adapun data hasil analisis siswa dari hasil selisih posttes kelas eksperimen dan kelas kontrol dapat dilihat pada Tabel 2. 
Tabel 2. data hasil posttest Kelas Eksperimen dan Kelas Kontrol

\begin{tabular}{ccc}
\hline Statistik & $\begin{array}{c}\text { Kelas } \\
\text { Eksperimen }\end{array}$ & $\begin{array}{c}\text { Kelas } \\
\text { Kontrol }\end{array}$ \\
\hline Jumlah & 2240 & 1768 \\
\hline $\begin{array}{c}\text { Skor } \\
\text { Minimm }\end{array}$ & 76 & 56 \\
\hline $\begin{array}{c}\text { Skor } \\
\text { Maksimum }\end{array}$ & 100 & 80 \\
\hline Rata-Rata & 89,6 & 71,68 \\
\hline $\begin{array}{c}\text { Standar } \\
\text { Deviasi }\end{array}$ & 7,659 & 39,89 \\
\hline Varians & 58,66 & 6,316 \\
\hline
\end{tabular}

Dari tabel diatas, dapat dilihat bahwa skor rata-rata nilai dengan menerapkan model pembelajaran kooperatif tipe Team Games Tournament adalah 89,6 dengan skor maksimum mencapai 100 sedangkan skor minimum yang di capai adalah 76. Sedangkan rata-rata kelas yang dalam proses pembelajaran menggunakan metode pembelajaran langsung adalah 71,68 dengan skor maksimum mencapai 80 sedangkan skor minimum yang di capai adalah 56. Adanya pengaruh sikap siswa menggunakan model pembelajaran kooperatif tipe team Games Tournament terhadap hasil belajar siswa pada materi Ikatan Kimia Kelas X SMA N 1 Kotamobagu.

\section{Uji Normalitas}

Sebelum melakukan pengujian hipotesis penelitian dengan menggunakan uji t-test, maka dilakukan uji Normalitas. Uji Normalitas ialah untuk melihat data yang digunakan berdistribusi normal atau tidak

\section{Uji Homogenitas}

Uji homogenitas adalah suatu pengujian untuk mengetahui apakah data yang digunakan bersifat homogen ataau tidak dengan kriteria jika Fhitung $<F_{\text {tabel }}$ data dikategorikan sebagai homogen.

Berdasarkan Tabel 3 dapat dilihat bahwa nilai Fhitung pada kelas eksperimen dan control sebesar $1,09<$ dari Ftabel $(\alpha=0,05)$ yaitu 4,26 sehingga dapat disimpulkan bahwa kedua kelas yaitu eksperimen dan kontrol adalah homogen.

Tabel 3. Ringkasan Uji Homogenitas

\begin{tabular}{ccc}
\hline Statistik & $\begin{array}{c}\text { Kelas } \\
\text { eksperimen }\end{array}$ & $\begin{array}{c}\text { Kelas } \\
\text { kontrol }\end{array}$ \\
\hline $\begin{array}{c}\text { Jumlah } \\
\text { responden }\end{array}$ & 25 & 25 \\
\hline Varians & 58,66 & 39,89 \\
\hline F hitung & 1,09 & \\
\hline F tabel & 4,26 & \\
\hline
\end{tabular}

Uji Hipotesis

Penelitian ini menggunakan rumus $t$-test [3]:

$$
\mathrm{t}=\frac{\overline{X_{1}}-\overline{\boldsymbol{x}_{2}}}{\sqrt{\frac{s_{1}^{2}}{n_{1}}+\frac{s_{2}^{2}}{n_{2}}}}
$$

Uji $t$ pada bagian ini dilakukan dengan tujuan untuk meguji hipotesis penelitian apakaha diterima $\left(\mathrm{H}_{\mathrm{a}}\right)$ atau ditolaknya hipotesis $\left(\mathrm{H}_{\mathrm{o}}\right)$, dimana: $\mathrm{H}_{\mathrm{o}}=$ tidak terdapat pengaruh penggunaan metode group investigation berbasis inkuiri terbimbing dan $\mathrm{H}_{a}=$ terdapat pengaruh menggunaan metode group investigation berbasis inkuiri terbimbing. Kriteria pengujian untuk rumus $t$-test ialah Hipotesis Alternatif $\left(\mathrm{H}_{\mathrm{a}}\right)$ diterima apabila thitung $>$ tabel dan Hipotesis Nihil (Ho) ditolak, sebaliknya jika hipotesis alternatif $\left(\mathrm{H}_{\mathrm{a}}\right)$ ditolak apabila thitung $<$ tabel dan hipotesis nihil (Ho) diterima.

Tabel 4. Perhitungan uji $t$-test

\begin{tabular}{|c|c|c|}
\hline Statistik & $\begin{array}{c}\text { Kelas } \\
\text { eksperimen }\end{array}$ & $\begin{array}{l}\text { Kelas } \\
\text { kotrol }\end{array}$ \\
\hline $\begin{array}{c}\text { Julah } \\
\text { responden }\end{array}$ & 25 & 25 \\
\hline $\begin{array}{c}\text { Rata-rata } \\
\text { selisih }\end{array}$ & 89,6 & 72,68 \\
\hline $\begin{array}{c}\text { Simpangan } \\
\text { Baku }\end{array}$ & 8,82 & 8,69 \\
\hline Varians & 7,6 & 6,3 \\
\hline Thitung & 8,95 & \\
\hline $\mathrm{T}_{\text {tabel }}$ & 2,05 & \\
\hline Kesimpulan & $\mathrm{ima} \mathrm{H}_{\mathrm{a}}$ & \\
\hline
\end{tabular}

Dapat dilihat dari Tabel 4. bahwa hasil pengujian diperoleh nilai thitung $=8,95$ pada taraf signifikan $\alpha=0,05$, dengan derajat kebebasan $(\mathrm{dk})=48$ diperoleh tabel $=2,05$. Nilai thitung $>$ tabel, maka $\mathrm{H}_{\text {a }}$ diterima dan Ho ditolak, sehingga terdapat dapat disimpulkan bahwa hasil belajar siswa yang menggunakan metode 
team games tournament lebih besar dari pada hasil belajar siswa tanpa menggunakan metode pembelajaran pembelajaran team games tournament pada materi ikatan kimia.

\section{Pembahasan}

Proses pembelajaran dengan menggunakan model pembelajaran kooperatif tipe TGT yang dilakukan pada kelas X IPA A (kelas eksperimen) dan model pembelajaran langsung yang dilakukan pada kelas X IPA B. Penelitian ini dilakukan selama 4 kali pertemuan untuk kelas X IPA A dan IPA B dengan pokok bahasan ikatan kimia.

Menurut pengamatan peneliti, siswa-siswa pada kelas eksperimen memiliki pemahaman yang lebih untuk materi ikatan kimia karena dalam model pembelajaran tipe TGT memiliki beberapa keunggulan, diantarannya model TGT ini dapat membuat peserta didik menjadi lebih senang dalam mengikuti pelajaran karena ada kegiatan permainan berupa tournament dalam model pembelajaran ini.

Untuk mengetahui terdapat perbedaan hasil belajar, digunakan uji perbedaan dua ratarata. Berdasarkan uji perbedaan dua rata-rata hasil belajar siswa pada kelas eksperimen yang dalam proses pembelajaran menggunakan model pembelajaran team games tournament dan pada kelas kontrol menggunakan metode pembelajaran langsung. Rata-rata kelas yang dalam proses pembelajaran menggunakan model pembelajaran Team Games Tournament adalah 89,6 dengan skor maksimum mencapai 100 sedangkan skor minimum yang dicapai adalah 76. Sedangkan rata-rata kelas yang dalam proses pembelajaran menggunakan metode pembelajaran langsung adalah 71,68 dengan skor maksimum mencapai 80 sedangkan skor minimum yang dicapai adalah 56. Hal ini juga dapat dilihat pada perhitungan statistik uji $\mathrm{t}$, dimana nilai thitung $=89,6>$ Ttabel $=$ 2,059. Dari hasil perhitungan ini memberi gambaran bahwa dalam proses belajar mengajar dengan menggunakan model pembelajaran kooperatif tipe TGT dan metode pembelajaran secara langsung. Sehingga hipotesis $\mathrm{H}_{0}$ ditolak dengan kata lain hipotesis diterima.

\section{Kesimpulan}

Berdasarkan hasil penelitian dan pembahasan diatas dapat disimpulkan hal-hal sebagai berikut : Terdapat perbedaan antara hasil belajar antara siswa yang diajarkan model pembelajaran kooperatif tipe TGT dengan siswa yang menggunakan model ceramah dan hasil dari penerapan model pembelajaran kooperatif tipe TGT pada kelas ekperimen dan model pembelajaran ceramah pada kelas kontrol di SMA Negeri 1 Kotamobagu, dapat disimpulkan rata-rata hasil belajar siswa menggunakan model pembelajaran kooperatif tipe TGT lebih tinggi daripada rata-rata hasil belajar siswa menggunakan pembelajaran ceramah pada materi ikatan kimia di SMA Negeri 1 Kotamobagu.

\section{Daftar Pustaka}

1. Budinimgsi, belajar dan pembelajran, PT rineka cipta, Indonesia, 2005

2. Nopiyanti T.; Haryono; Ashdi; Penerapan model pembelejaran kooperatif tipe Team Game Tournament (TGT) untuk meningkatkan prestasi belajar kimia dan kreativitas siswa pada materi reaksi redoks kelas $X$ semester genap SMA Negeri 3. 2013. Vol 2. Hal 163

3. Sugiono; Metode penelitian pendidikan pendidikan pendekatan kuantitatif dan kuatitatif. Bandung. Indonesia, 2013 